\title{
DILEMA KEBIJAKAN RELOKASI PEDAGANG KAKI LIMA (PKL) KE PASAR BLAURAN II KOTA SALATIGA
}

\author{
M. Isa Thoriq ${ }^{1}$ dan Muchamad Samsudin ${ }^{2}$
}

\begin{abstract}
The informal sector contributes greatly to the nation's economic development. Among the various forms of economic activity in this sector are street traders (PKL). The existence of street traders in various places has driven the economy of the community, but without good management, it will cause problems. The city of Salatiga as one of the cities in Central Java has an attraction for street traders, the existence of street traders in this city has experienced ups and downs due to the socio-economic conditions of the community. The government always regulates and manages the existence of street traders. In this case, the City Government of Salatiga through the Trade Office relocated street vendors who were on "Jalan Taman Pahlawan" to Blauran II Market. This study uses a qualitative descriptive method that looks at the problem of formulation of street traders relocation policy. Based on the conclusions of the results of this study that the incremental model of the formulation of street traders relocation has a direct impact on the street traders and the construction of Blauran II Market.
\end{abstract}

\section{Keywords: Street Traders (PKL), Incremental Policy Formulation}

\section{PENDAHULUAN}

Pengangguran berdampak pada kemiskinan dan ketimpangan pendapatan penduduk di perkotaan. Salah satu solusinya adalah melalui pengembangan dan penciptaan lapangan kerja di sektor informal ${ }^{3}$. Pedagang kaki lima (PKL) merupakan salah satu sektor informal yang banyak terdapat di perkotaan. Keberadaan PKL dapat menyediakan lapangan kerja baru. Sebagian masyarakat menjadikannya sebagai pilihan alternatif bagi yang tidak tertampung di sektor formal. Keterlibatan sektor informal lebih diakibatkan karena keterpaksaan saja dibanding sebagai pilihan, hal ini terjadi karena tekanan dari sistem ekonomi yang tidak memberi tempat bagi mereka yang tidak mempunyai pendidikan dan ketrampilan yang mencukupi ${ }^{4}$.

\footnotetext{
${ }^{1}$ Pegawai Inspektorat Provinsi Jawa Tengah

2 Pegawai Pemerintah Kota Salatiga

${ }^{3}$ Dawan Rahardjo, Menuju Indonesia Sejahtera: Solusi Konkret Pengetasan Kemiskinan,. Khanata, Pustaka LP3ES Indonesia. Jakarta, hlm. 7

${ }^{4}$ Didik J Rachbini, Abdul Hamid, Ekonomi informal perkotaan: gejala involusi gelombang kedua. Pustaka LP3ES Indonesia, Jakarta, hlm. 32
} 
Sensus ekonomi yang dilaksanakan oleh Badan Pusat Statistik tahun 2016 mengungkapkan bahwa jumlah pelaku usaha PKL di Indonesia sebanyak 26,7 juta orang atau $10 \%$ dari penduduk Indonesia ${ }^{5}$. Hal ini menimbulkan permasalahan tersendiri dimana keberadaan PKL sering dianggap mengganggu ketertiban. PKL seringkali menggunakan ruang publik, seperti di trotoar, bahu jalan, taman kota dan sebagainya, yang sebenarnya bukan tempat untuk berjualan yang berakibat mengganggu lalu lintas dan keindahan. Para pengguna jalan juga dirugikan dengan menyempitnya ruas jalan. Keberadaan PKL tidak dapat dihindari, oleh sebab itu Pemerintah bertanggung jawab untuk mengatur dengan berbagai macam regulasi. Hampir setiap upaya dalam melakukan penataan tata ruang kota selalu saja memunculkan masalah yang sama tentang PKL, yaitu kurangnya dalam pembinaan dan penataan secara komprehensif.

Permasalahan tersebut juga terjadi di Kota Salatiga. Dinas Perdagangan Kota Salatiga $^{6}$ menyebutkan tahun 2017 jumlah PKL di Kota Salatiga mencapai 1.420 orang, jumlah tersebut tidak sedikit, sehingga muncul permasalahan dalam pengelolaan PKL terutama mengenai penataan lokasi. Berbagai upaya yang dilakukan Pemerintah Kota Salatiga berhasil menekan jumlah PKL. Penelitian yang dilakukan oleh Frans Wilson $\mathrm{Kuat}^{7}$ menemukan dua penyebab utama mengapa jumlah PKL mengalami penurunan. Pertama, banyak PKL yang telah sukses dalam usaha sehingga status mereka bukan lagi PKL tetapi telah menjadi pedagang eksis bahkan pedagang toko. Kedua, penegakkan Perda secara konsisten dan bertanggung jawab oleh Pemerintah Kota lewat Satpol PP dan Dinas Perdagangan yang tidak kompromi dengan daerah larangan sehingga tidak ada PKL liar.

\footnotetext{
5 Badan Pusat Statistik, Sensus Ekonomi 2016 , https:// webapi .bps.go.id /consumen/ 01f841a1ac26bcad4b777 e96cc01ca? redirect_uri=https:/www.bps.go.id/publication/ 2017/12/27 /c2800fd0d3b253ec159d8a14/ peta-sensus-ekonomi-2016.html, pada tanggal 30 September 2018

${ }^{6}$ Wawancara dengan Kasi Pemberdayaan dan Perlindungan Pasar Tradisional Dinas Perdagangan Kota Salatiga

${ }^{7}$ Frans Wilson Kuat, Partisipasi Publik dan Harmoni Sosial: Studi Kasus Perumusan Peraturan Daerah Nomor 2 Tahun 2003 tentang Penataan Pedagang Kaki Lima Kota Salatiga, Desertasi Doktoral UKSW
} 


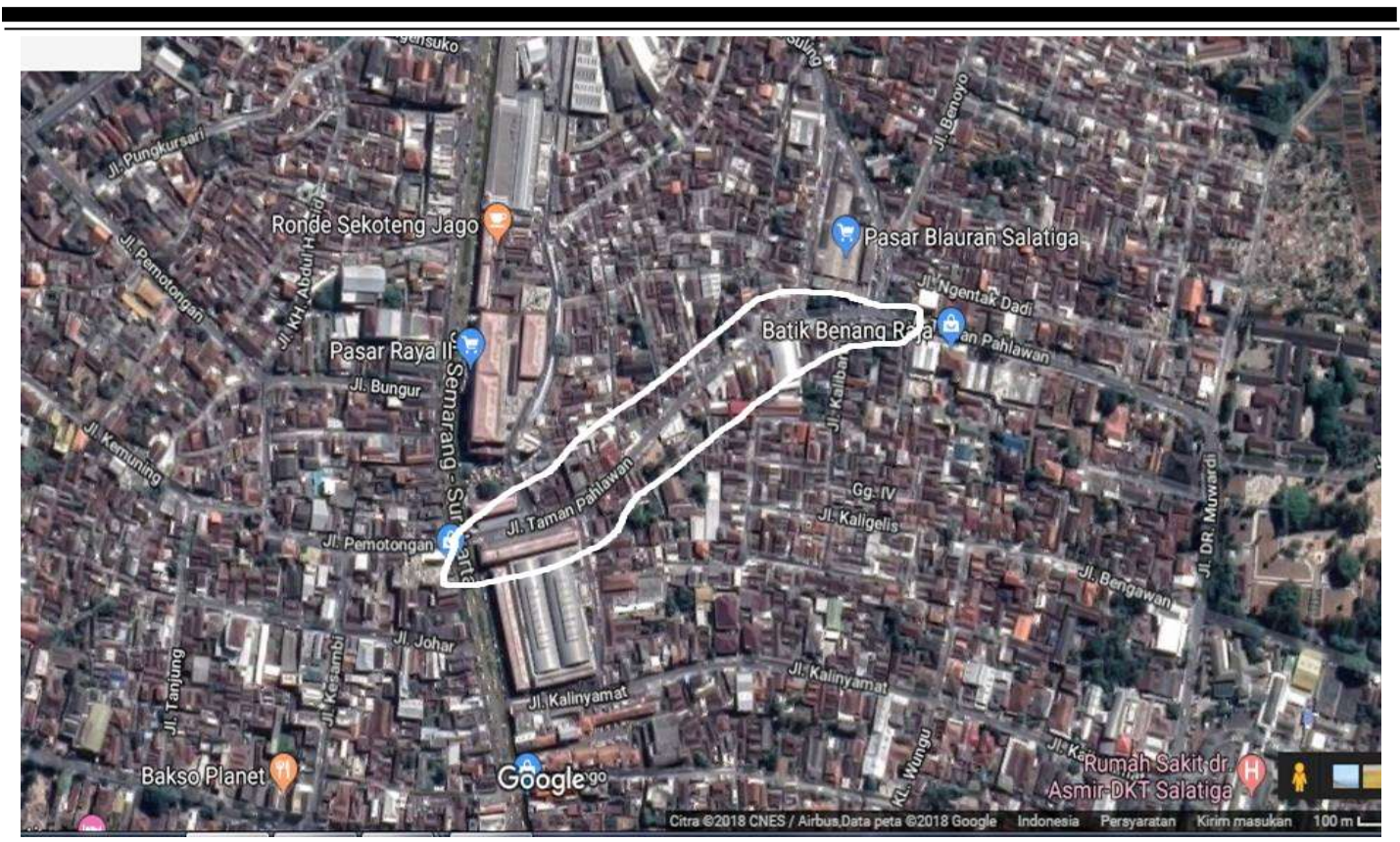

Gambar I. Lokasi PKL yang direlokasi

Pemerintah Kota Salatiga melakukan upaya penertiban dan penataan PKL salah satunya di Jl. Taman Pahlawan melalui program relokasi PKL ke Pasar Blauran II. Kementerian Perindustrian dan Perdagangan memberikan bantuan kepada Pemerintah Kota Salatiga untuk membangun kembali Pasar Blauran II yang akan menjadi tempat relokasi. Bantuan tersebut untuk menampung para PKL yang berjualan di Jl. Taman Pahlawan. Pemerintah Kota Salatiga telah meresmikan Pasar Blauran II namun para pedagang tetap kembali berdagang diluar area pasar. Hal ini membuat Pemerintah Kota Salatiga terus melakukan razia dan penertiban, dalam pengamatan langsung penulis melihat saat petugas pergi, para pedagang kembali lagi berjualan di jalan. Berdasarkan kondisi diatas, studi ini akan melihat bagaimana proses formulasi kebijakan relokasi PKL ke Pasar Blauran II.

Jenis penelitian ini merupakan jenis penelitian deskriptif, karena dalam penelitian ini mendeskripsikan keadaan yang terjadi secara sistematis dan faktual dengan tujuan untuk memaparkan serta penyelesaian dari masalah yang diteliti. Peneliti tidak mengubah, menambah, atau mengadakan manipulasi terhadap objek atau wilayah penelitian. Peneliti hanya memotret apa yang terjadi pada diri objek atau wilayah yang diteliti, kemudian memaparkan apa yang terjadi dalam bentuk laporan penelitian secara 
lugas, seperti apa adanya ${ }^{8}$. Teknik pengumpulan yang digunakan yaitu wawancara mendalam dan langsung kepada informan yang memiliki peranan langsung dalam mengimplementasi kebijakan relokasi PKL dan kepada kelompok sasaran yang terkena dampak dari kebijakan relokasi tersebut. Data yang diperoleh kemudian dianalisa melalui tiga alur kegiatan yang terjadi secara bersamaan, yaitu reduksi data, penyajian data, dan penarikan kesimpulan/verivikasi.

\section{PEMBAHASAN}

Formulasi kebijakan sebagai bagian dalam proses kebijakan publik merupakan tahap yang paling penting, karena implementasi dan evaluasi kebijakan hanya dapat dilaksanakan apabila tahap formulasi kebijakan telah selesai, disamping itu kegagalan suatu kebijakan atau program dalam mencapai tujuan-tujuannya sebagian besar bersumber pada ketidaksempurnaan pengolahan tahap formulasi ${ }^{9}$.

Menurut Dunn ${ }^{10}$ perumusan kebijakan (policy formulation) adalah pengembangan dan sintesis terhadap alternatif-alternatif pemecahan masalah. Winarno ${ }^{11}$ menyatakan bahwa masing-masing alternatif akan bersaing kemudian di pilih sebagai kebijakan dalam rangka memecahkan masalah.

Pemerintah Kota Salatiga dalam hal ini Dinas Perdagangan (Disdag) Kota Salatiga melihat permasalahan PKL di Jl. Taman Pahlawan sebagai sebuah pelanggaran yang harus ditertibkan. Keberadaan PKL dianggap mengganggu ketertiban di jalan tersebut, sesuai dengan tugas pokok dan fungsi Dinas Perdagangan Kota Salatiga yang tertuang dalam Peraturan Walikota Salatiga Nomor 39 Tahun 2016 Tentang Kedudukan, Susunan Organisasi, Tugas dan Fungsi serta Tata Kerja Dinas Perdagangan maka Dinas Perdagangan Kota Salatiga berkewajiban melakukan penataan PKL. Menyelesaikan permasalahan PKL Dinas Perdagangan Kota Salatiga melakukan tahapan formulasi kebijakan sebagai berikut:

\footnotetext{
${ }^{8}$ Arikunto, Prosedur Penelitian Suatu Pendekatan Praktik. Jakarta, Rineka Cipta, 2010, hlm. 3

${ }^{9}$ Samodra Wibawa, Evaluasi Kebijakan Publik. Jakarta: PT Raja Grafindo Persada, Jakarta, 1994, hlm. 2

10 Wiliam N Dunn, Pengantar Analisis Kebijakan Publik. Yogyakarta. Gadjah Mada University Press, 2000, hlm. 92

${ }^{11}$ Budi Winarno, Teori dan Proses Kebijakan Publik, Yogyakarta. Media Press, 2002, hlm. 29
} 
1. Pendataan PKL

Dinas Perdagangan Kota Salatiga bekerjasama dengan Pusat Layanan Psikologis Satya Wacana melakukan pendataan jumlah PKL yang akan menempati Pasar Blauran II melalui wawancara kepada para PKL. Dari pendataan ini diketahui dan diklasifikasi PKL yang akan direlokasi berdasarkan Surat Tanda Daftar Usaha Pedagang Kaki Lima (STDU PKL) dan Kartu Tanda Penduduk (KTP). Prioritas diberikan kepada yang memiliki STDU PKL dan berdomisili di Kota Salatiga.

2. Penempatan

PKL yang sudah terdata dan memenuhi syarat kemudian di tempatkan ke tempat yang sudah disediakan di Pasar Blauran II. Pembagian tempat berdasarkan jenis dagangan yang dijual.

3. Evaluasi

Evaluasi atau pemantauan akan dilakukan oleh Dinas Perdagangan Kota Salatiga dalam waktu 6 bulan setelah penempatan pedagang.

Menurut Anderson (1979) untuk melihat sebuah Formulasi Inkremental kita dapat mengetahui melalui mekanisme sebagai berikut:

$\underline{\text { Menyeleksi tujuan-tujuan atau sasaran dan langkah analisis empiris diperlukan }}$ untuk mencapai tujuan-tujuan tersebut

Proses kebijakan relokasi ini bertujuan untuk membina para PKL, menertibkan PKL dan merevitalisasi pasar tradisional. Kemudian Dinas pasar melihat bahwa tujuan utamanya adalah merelokasi PKL dalam arti menempatkan kembali para pedagang ke tempat yang sudah disediakan, dengan begitu permasalahan PKL akan selesai. Perlu diketahui bahwa pasar Blauran II ini sebelumnya sudah ada, namun karena kondisinya sudah lama, banyak bagian yang rusak, sehingga pedagang memilih berjualan di luar sebagai PKL.

Pembuat keputusan mempertimbangkan hanya pada beberapa alternatif pemecahan masalah dan hanya pilihan-pilihan yang sifatnya marginal dari

\section{kebijakan yang sudah ada.}

Dinas Perdagangan sebagai pembuat keputusan melihat bahwa dari tujuan yang sudah ditetapkan maka dibuatlah alternatif yang paling mudah yakni mengembalikan lagi pedagang diluar pasar dengan membuat tempat yang baru. Dinas Perdagangan tidak membuat kajian intensif tentang pengelolaan pasar dari segi bisnis, promosi dan 
infrastruktur. Hal ini terlihat dari keterangan Pedagang yang mengatakan bahwa kondisi parkir yang susah dan lokasi yang tidak mendukung membuat dagangan sepi dari pembeli.

Perlu nya dibuat pengawasan yang ketat terhadap pedagang yang kembali jualan di luar pasar, sanksi tegas harus di tegakan. Hal ini menunjukan bahwa pembuat kebijakan tidak memprediksi kan permasalahan yang datang dikemudian hari.

Permasalahan yang hadapi pembuat kebijakan adalah perubahan secara terus menerus, tidak melihat dampak kedepan dan tanpa pertimbangan apakah keputusan itu merupakan cara yang tepat untuk mencapai sasaran

Kebijakan relokasi ini tidak dipertimbangkan secara komprehensif, sehingga dimungkinkan kebijakan ini akan diikuti oleh kebijakan lain yang sifatnya akan menambal sulam kebijakan yang lama. Dinas Perdagangan Kota Salatiga memanfaatkan program dari Pemerintah Pusat yakni Program Pembangunan Revitaliasi Pasar dari Kementerian Perdagangan Republik Indonesia. Dalam program ini Pemerintah Kota Salatiga mendapatkan bantuan melalui Dana Alokasi Khusus (DAK) untuk merevitalisasi Pasar Blauran II. Dengan demikian relokasi PKL ke pasar Blauran II mengabaikan kebutuhan pedagang dan juga kondisi pasar setelah revitalisasi tidak sesuai dengan Pasal 41 Perda Kota Salatiga Nomor 12 Tahun 2013 Tentang Pengelolaam, Pemberdayaan dan Perlindungan Pasar Tradisional yang mengatur tentang pembenahan pasar secara fisik yang meliputi:

a) pembenahan tata letak;

b) pengaturan lalu lintas orang dan barang di dalam lingkungan Pasar;

c) peningkatan kualitas konstruksi;

d) pembenahan sistem air bersih dan limbah;

e) pembenahan sistem elektrikal;

f) penggunaan sistem pencegah kebakaran; dan

g) pembenahan sistem penanganan sampah.

Dari analisa diatas dapat dilihat Kebijakan Relokasi PKL ini merupakan kebijkan inkremental yang dijalankan oleh Pemerintah Kota Salatiga. Model formulasi kebijakan seperti ini terjadi karena dua hal yakni:

1. Keterbatasan Dana dan Waktu 
Pemerintah Kota Salatiga dalam kebijakan relokasi PKL di Jl. Taman Pahlawan memanfaatkan program Revitalisasi Pasar Tradisional dari Kementerian Perindustrian dan Perdagangan. Guna menunjang program tersebut maka dibuatlah program pendukung berupa relokasi, yang pada proses perencanaan kurang memperhatikan aspek sarana prasarana.

\section{Mengambil Gagasan Yang Praktis Dari Alternatif}

Pengambil kebijakan tidak melakukan upaya sistematis dan komprehensif dalam perumusan kebijakan. Sebaliknya, mereka mengambil upaya praktis, yakni pemindahan ke pasar Blauran II yang tengah di revitalisasi oleh Kementerian Perindustrian dan Perdagangan.

Dari kebijakan inkremental tersebut dampaknya adalah permasalahan yang muncul tidak dapat diantisipasi, dan keberadaan pasar Blauran II menjadi tidak efektif, efisien dan ekonomis.

Tabel 1 Perbandingan Teori Inkremental (Anderson) dengan Penataan PKL di

\section{Salatiga}

\begin{tabular}{|l|l|l|}
\hline \multicolumn{1}{|c|}{ Fakta Relokasi PKL } & \multicolumn{3}{|c|}{ Tahapan Inkremental } \\
\hline $\begin{array}{l}\text { Dinas Perdagangan menyeleksi beberapa } \\
\text { sasaran empiris yaitu relokasi PKL dan } \\
\text { revitalisasi pasar }\end{array}$ & $\begin{array}{l}\text { Menyeleksi tujuan-tujuan atau sasaran } \\
\text { empiris }\end{array}$ \\
\hline $\begin{array}{l}\text { Pedagang yang berjualan di jalan, } \\
\text { dikembalikan ke Pasar Blauran II }\end{array}$ & $\begin{array}{l}\text { Alternatif kebijakan yang bersifat } \\
\text { marginal }\end{array}$ \\
\hline $\begin{array}{l}\text { Muncul permasalahan lain soal } \\
\text { keamanan, parkir, fasilitas, dan pedagang } \\
\text { yang kembali berjualan di jalan }\end{array}$ & Permasalahan terjadi terus menerus \\
\hline
\end{tabular}

Sumber: Diolah oleh Peneliti

\section{PENUTUP}

Kebijakan untuk merelokasi PKL di Jl. Taman Pahlawan ke Pasar Blauran II merupakan formulasi kebijakan model inkremental. Formulasi kebijakan model ini bukan berarti buruk, namun demikian dalam kondisi ideal tentu akan lebih baik jika menggunakan model yang lain, misalnya model pilihan rasional yang lebih mempertimbangkan informasi yang ada, kemungkinan peristiwa, dan potensi biaya dan keuntungan dari menentukan pilihan, dan bertindak konsisten dalam memilih tindakan terbaik. Dampak dari model inkremental ialah akan muncul permasalahan yang berkelanjutan, yang kemudian akan membuat pemerintah membuat kebijakan lagi untuk 
mengatasi masalah dari kebijakan sebelumnya. Permasalahan lanjutan dari kebijakan ini adalah kembalinya para pedagang ke jalan.

Pemerintah Kota Salatiga dalam penanganan PKL ialah lebih mengupayakan penataan secara komprehensif dan melakukan upaya persuasif kepada para PKL. Perlunya penetapan regulasi lanjutan terhadap hasil pendataan para pedangang yang berjualan di Jl. Taman Pahlawan untuk ditempatkan ke dalam Pasar Blauran II, sehingga dalam menempatkan mereka ke dalam pasar memiliki dasar yang kuat.

Diperlukannya alokasi anggaran guna pembangunan infrastruktur pendukung yang sesuai dengan kebutuhan pedagang maupun konsumen yang ada didalamnya, sehingga baik para pedagang maupun konsumen di pasar nyaman berbelanja. Perlu kajian lebih lanjut mengenai pengelolaan pasar dengan sistem manajemen yang lebih baik. Misalnya pengelolaan pasar dengan manajemen Perusahaan Daerah, sehingga nantinya pengelolaan pasar menjadi lebih baik, antara lain lebih teratur, kebersihan terjaga serta keamanan terjamin. Upaya penertiban para PKL bisa dilakukan dengan lebih memaksimalkan kegatan penegakan hukum, misalnya penempatan petugas Satpol di lokasi pelanggaran seharian dan secara rutin, pemasangan CCTV, sehingga begitu terdapat pelanggaran langsung ditindak. Penetapan dan pelaksanaan sanksi yang jelas terhadap para PKL yang masih melanggar aturan. Membuat dan melaksanakan aturan pemberian sanksi yang lebih tepat dan jelas baik kepada para pedagang maupun konsumen yang masih melaksanakan aktivitas jual-beli di jalan.

\section{DAFTAR PUSTAKA}

Agustino, Leo. 2008. Dasar- dasar Kebijakan Publik.Bandung. Alfabeta

Anderson, James, 1979, Public Policy Making. Holt, Rinehat \& Winston

Arikunto, S. 2010. Prosedur Penelitian Suatu Pendekatan Praktik. Jakarta: Rineka Cipta. Bungin, B. 2007. Analisis data penelitian kualitatif. Yogyakarta. PT Raja Grafindo Persada.

Dawam Rahardjo. 2006. Menuju Indonesia Sejahtera: Solusi Konkret Pengetasan Kemiskinan. Jakarta: Khanata, Pustaka LP3ES Indonesia

Dunn, William N. 2000. Pengantar Analisis Kebijakan Publik. Yogyakarta. Gadjah Mada University Press.

Dwijayanti, Oktarina. 2006. Karakteristik Berlokasi PKL di Kawasan Perdagangan Jalan Kartini Kota Semarang. 
Hessel Nogi S. Tangkilisan, 2003. Implementasi Kebijakan Publik. Jakarta. Grasindo

Islamy, Irfan. 2003. Prinsip-Prinsip Perumusan Kebijaksanaan Negara. Jakarta: Bina Aksara.

Kuat, F. W. (2017). Partisipasi Publik dan Harmoni Sosial: Studi Kasus Perumusan Peraturan Daerah Nomor 2 Tahun 2003 tentang Penataan Pedagang Kaki Lima Kota Salatiga (Doctoral dissertation, Doktor Studi Pembangunan Program Pascasarjana UKSW).

Rachbini, Didik J., dan Abdul Hamid. Ekonomi informal perkotaan: gejala involusi gelombang kedua. Pustaka LP3ES Indonesia, 1994

Taufiqurakhman, 2014. Kebijakan Publik : Pendelegasian Tanggungjawab Negara Kepada Presiden Selaku Penyelenggara Pemerintahan. Jakarta Pusat. Fakultas Ilmu Sosial dan Politik Universitas Moestopo Beragama (Pers)

Wibawa, Samodra.1994. Evaluasi Kebijakan Publik. Jakarta : PT Raja Grafindo Persada Yeung dan Mc Gee. 1977. Hawkers in Southeast Asian Cities: Planning for The Bazaar Economy. Ottawa: International Development Research Centre. 